\title{
土砂直投エにより発生する濁りの挙動特性 に関する数值解析
}

\section{NUMERICAL SIMULATION ON CHARACTERISTICS OF TURBIDITY TRANSPORT GENERATED IN DIRECT DUMPING OF SOIL}

\author{
玉井昌宏1・村岡浩爾 2 \\ Masahiro TAMAI and Kohji MURAOKA \\ ${ }^{1}$ 正会員 工博 大阪大学助教授 工学部土木工学科（广565 吹田市山田丘 2-1)

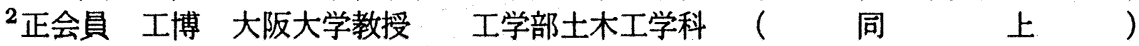

\begin{abstract}
A silt curtain is commonly used in a reclamation work to reduce outflow of turbidity from construction area. However it's quite difficult to get an appropreate drawing plan of the curtain since there is little information about a series of real phenomena which occurs under the sea, with the exception of some laboratory experiments with small scale in which we can't remove scale effect. In this study, we carried out two-dimensional numerical simulation with a scale of the construction site using the two-fluid model with the $\mathrm{k}-\epsilon$ turbulence model to investigate turbidity transport generated by direct dumping of soil using a hopper barge with bottom doors. We briefly discussed characteristics of turbidity transport and effectiveness of the silt curtain.
\end{abstract}

KeyWords. turbidity, particle, two-phase flow, numerical simulation

\section{1. はじめに}

海域において埋め立て工事を行なう場合, 各種工法 において発生した濁りの工事区域外への流出を抑制す るために，区域全体を取り囲むように污濁防止幕が仮 設されるのが一般的である.これまでの使用実績から， 防止幕の有効性については実証されているものと判断 できるだろう. しかしながら，基礎的な研究は散見され るものの1),2),3)，展張や配置計画を策定するためのバッ クグラウンドとなる知見は意外に少ない.

こひことを展張方法を例に挙げて説明しよう。防止 幕は一枚で全水深にわたって展張されるのではなく, 水 面から半水深付近までカバーする垂下式と水底から半 水深付近までの自立式に分割され, 両者は水平方向に $50 \sim 100 \mathrm{~m}$ 程度離して設置されるのが一般的である.こ のような展張形式を選択する理由は, 主として幕に作 用する流体力を軽減させることにあるが，濁りの流出 抑制効果にとって最適かどうかは不明である. 恐らく 流体力（展張力）軽减と濁りの流出抑制効果向上の間に はトレードオフの関係があるものと推察されるが，こ うした点についてはこれまでほとんど議論されていな いのである.

污濁防止幕の有効性に関する模型実験に行なうにし
ても，スケールの影響を除去することは不可能である. その一方で，試験工事などの現地観測データ4),5) も非 常に少ない. 精度高い数值予測手法を構筑するために は, 高濃度混相流の乱流構造のモデル化など, 当面解 決されそうにない課題が山積している.

類似した課題に対して個別要素法を基礎とした解析 法等が提案されているものの ${ }^{6)}$, 室内実験との比較が行 われている程度であり，大規模な現地スケールへ適用 された例は見られない。

污濁防止幕による濁りの捕捉メカニズム,つまり, 潮 流など周囲環境流動による輸送を抑制するのか, 土砂 直投工によって生じる誘起流動場を抑制するのかといっ た問題，あるいは濁りの発生や拡がり機構等の問題に ついて定性的な現象把握もほとんどなされていないの が現状である.

ここでは, 筆者らが粒子プルーム流動解析に用いた 2 流体モデルを用いて, 現地スケールの土砂直投工に よる濁りの発生と拡がり過程に関する数値計算を実施 する. 誘起流動や濁りの規模や空間的な拡がりの目安 を得ることにより, 污濁防止幕が工事区域の数百メー トル外側に設置されること等の従来の展張方式を勘案 して, 污濁流出抑制機構に当りをつけようというのが 本研究の趣旨である. 
㳖-1 計算条件（投下条件）

\begin{tabular}{|l||c|c|c|c|c|}
\hline CASE & 1 & 2 & 3 & 4 & 5 \\
\hline$Q\left(\mathrm{~m}^{3}\right)$ & 3000 & 3000 & 3000 & 2500 & 3500 \\
\hline$q\left(\mathrm{~m}^{2}\right)$ & 60 & 60 & 60 & 50 & 70 \\
\hline$t_{D}(\mathrm{~s})$ & 10 & 5 & 20 & 10 & 10 \\
\hline$U_{D}(\mathrm{~m} / \mathrm{s})$ & 1.5 & 3.0 & 0.75 & 1.25 & 1.75 \\
\hline
\end{tabular}

衣-2 S S 総発生量 ${ }^{4}$

\begin{tabular}{|l||c|c|c|c|}
\hline ケース & 2 & 3 & 4 & 5 \\
\hline$m(\mathrm{~kg})$ & 5,040 & 14,990 & 10,910 & 9,230 \\
& 8,680 & 11,310 & 24,090 & 11,990 \\
\hline$Q\left(\mathrm{~m}^{3}\right)$ & 3,065 & 3,010 & 3,354 & 3,264 \\
\hline$m / Q\left(\mathrm{~kg} / \mathrm{m}^{3}\right)$ & 1.6 & 5.0 & 3.3 & 2.8 \\
& 2.8 & 3.8 & 7.2 & 3.7 \\
\hline$r a * 10^{3}$ & 0.62 & 1.9 & 1.2 & 1.1 \\
& 1.1 & 1.4 & 2.7 & 1.4 \\
\hline
\end{tabular}

\section{2. 数値解析の概要}

\section{（1）基本的な考元方}

数値計算を実行するにあたり，一連の現象に対する 基本的な考え方を以下に示す.

1）濁りの移流，拡散は直投士砂により誘起される流 動場のみに支配される. 周囲環境の流動は考慮し ない.

2）投下される土砂は，投下点直下近傍に全て崔䅡する 粗な土粒子と, 投下点近傍では堆積しない細かい 土粒子との 2 粒径砂とする. 粗な粒子は誘起流動 の形成のみに関与する. また，投下された細砂量 がそのまま污濁負荷量となって拡散する.

3) 粗粒子どうしの衝突, 粗粒子の底面一の衝突, 堆積 過程の誘起流動場への影響は無視する。

4）誘起流動場の速度の規模が濁りの沈降速度より遥か に大きいことから，濁質の沈降の影響を無視する. また, 堆積している濁質の（再）浮上は考虑しない。

5) 投下時に生じる水表面の変動は考慮しない.

6）誘起流動場の計算において濁質成分の体積や密度効 果はこれを無視し, 濁りについては拡散方程式に より解析する.

7) 底開バージの船長 $(50 \mathrm{~m}$ 程度)に比較して, 水深 $(20$ $\mathrm{m}$ 程度)が小さいので, 船長方向に直角な断面内の 鈆直 2 次元現象と考える.

\section{(2) 計算モデルの概要}

計算手法が具備すべき条件として,

1）土砂直投工により生じる流れは粒子と流体の相対運 動により誘起される. 従って, 粒子運動について も流体運動と同程度の精度で予測できること。つ まり相別の運動方程式が必要であること.

2) 対象流動が固体粒子を高濃度で含んでいることから, 相排除の効果が考慮されていること．また，無数 の粒子が無理なく取り扱えること。

3）粒子混入による乱流変調がなるべく考慮できること. の以上 3 つ項目を設定した.

混相流を対象とした数值予測手法は相の構成や全体 の流動の規模等に応じて様々なレベルが考案されてい る.それらは，両相を一つの混合体とするモデル，分 散相と連続相をそれぞれラグランジュとオイラー方程 式により表示するモデル（D Pモデル），両相を相別に オイラー方程式により表示するモデル (2流体モデル) に大別できる. 条件1)よりD Pモデルあるいは 2 流体 モデルの適用が妥当であろう. 最近, 当該分野に対し てもD Pモデルが適用される傾向にあるが，実工事の スケールで条件 2)を満足することは難しいだろう。こ のような状況から，ここでは 2 流体モデルを利用する.

誘起流動場の解析に用いた基䃈方程式は以下に示す とおり, 両相の体積率 $\Phi_{k}$ の保存方程式, 流体相粒子相 の 2 方向流速成分の運動方程式 $U_{k i}$, 全相の体積率の合 計に関する式の全 7 式である.

$$
\begin{aligned}
& \left(\rho_{k} \Phi_{k}\right)_{, t}+\left(\rho_{k} \Phi_{k} U_{k j}\right)_{, j}+\left(\rho_{k} \overline{\phi_{k} u_{k j}}\right)_{, j}=0 \\
& \underbrace{\left(\rho_{k} \Phi_{k} U_{k i}\right)_{, t}+\left(\rho_{k} \overline{\phi_{k} u_{k i}}\right)_{, t}}_{\text {時蔺项 }}+\underbrace{\left(\rho_{k} \Phi_{k} U_{k i} U_{k j}\right)_{j}}_{\text {刘䂗項 }} \\
& =\underbrace{-\rho_{k}\left(\Phi_{k} \overline{u_{k i} u_{k j}}+U_{k i} \overline{\phi_{k} u_{k j}}+U_{k j} \overline{\phi_{k} u_{k i}}\right)_{, j}}_{\text {乱流相關項 }} \\
& -\underbrace{\left.\rho_{k} \overline{\left(\phi_{k} u_{k i} u_{k j}\right.}\right)_{, j}}_{\text {乱诜相関項 }}-\underbrace{\left(\Phi_{k} P_{, i}+\overline{\phi_{k} p_{, i}}\right)}_{\text {压力項 }}+\underbrace{\rho_{k} \Phi_{k} g_{i}}_{\text {重力項 }} \\
& +\underbrace{\sum_{k^{\prime}=1}^{k} F_{k}\left\{\Phi_{k^{\prime} i}\left(U_{k^{\prime} i}-U_{k i}\right)+\overline{\phi_{k^{\prime}}\left(u_{k^{\prime} i}-u_{k i}\right)}\right\}}_{\text {相阔応力項 }} \\
& \sum_{k=1}^{k} \Phi_{k}=1
\end{aligned}
$$

ここに, $\rho_{k}$ :第 $k$ 相の密度, $\Phi_{k}: k$ 相の体積率, $U_{k i}: k$ 相 の $i$ 方向の流速成分, $P$ : 圧力, $g_{i}: i$ 方向の重力加速度 である. $\sum_{k=1}^{k}$ は全相について合計すること， $k^{\prime}$ は $k$ 相 以外の相であることを意味している. 以下では $k=f, p$ はそれぞれ流体相と粒子相であるものとする. 
(2) 式の相間応力項の $F_{k}$ は次式のように与えられる.

$$
F_{k}=18 Z \nu_{f} / d^{2}
$$

$Z$ は 1 次から 2 次への抵抗則の遷移領域において，ス トークス則を用いるための補正係数であり，次式のよ うに表示される。

$$
Z= \begin{cases}\left(1+0.15 R_{e}\right)^{0.687} & \left(R_{e} \leq 1000\right) \\ 0.43 R_{e} / 24 & \left(R_{e}>1000\right)\end{cases}
$$

ここで, $R_{e}$ は粒子レイノルズ数であり, $R_{e}=\left|\vec{U}_{p}-\vec{U}_{f}\right|$ $d_{p} / \nu_{f}$ と定義される. $d_{p}:$ 粒径, $\vec{U}_{k}: k$ 相の流速べクト ル, $\nu_{f}:$ 流体相の動粘性係数である.

各種乱流相関項の完結方法は, 基本的には単相乱流 に対して用いられているものと同様である. また, 渦動 粘性係数, 拡散係数の導出には, Elghobashi et al. ${ }^{7), 8)}$ の乱流モデルを用いる. 固体粒子が高濃度で混入した 場合の乱流変調に関しては基礎的なデータもなく, 乱 流モデルも開発されていない状況にある.ここでは低 濃度の混相流に対して開発された同モデルをそのまま 適用する. 相関項の完結, 乱流モデルの詳細について は参考文献 7),8) を参照されたい. また, 流動場の数値

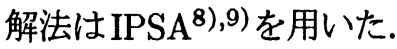

2 流体モデルでは相排除の効果が考慮されており，濁 質成分は流体相中に含まれるので, 濁質濃度 $C$ の保存 方程式は次式のようになる.

$$
\begin{aligned}
&\left(\Phi_{f} C\right)_{, t}+\left(\Phi_{f} U_{f j} C\right)_{, j}+\left(\Phi_{f} w_{0} C\right)_{, z} \\
&=-C \overline{\phi_{f} u_{f j}}+U_{f j} \overline{\phi_{f} c}+\Phi_{f}{\overline{u_{f j} c}}_{, j} \\
&-{\overline{\phi_{f} u_{f j} c}}_{, j}+w_{0} \bar{\phi}_{f} C,{ }_{, z}+q
\end{aligned}
$$

ここに, $C$ : 濁質濃度, $z$ : 鉛直座標 $w_{0}$ : 濁質の沈降速 度, $q$ : 濁質負荷量である. 各種乱流相関の完結方法は, (2)式と同様である. 本計算では, 濁質成分と水流の相 対運動を無視しており, 濁質の拡散係数についても流 体相の体積率 $\Phi_{f}$ のそれと同一であると仮定した.

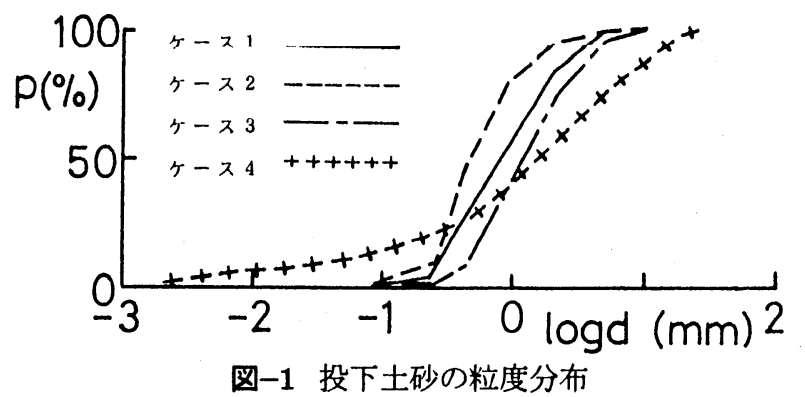

\section{3. 計算領域と条件}

\section{(1) 計算領域}

本計算では, 污濁防止幕の存在を考慮しないので, 計 算される現象は投下点を中心として左右対称となるは
ずである.ここでは, その右側半分について計算する. 計算領域は, 鉛直 (水深) 方向 $20 \mathrm{~m}$, 水平方向 $160 \mathrm{~m}$ の 鉛直 2 次元断面である. 関空二期工事程度の水深と工 事区域から污濁防止幕までの距離 (数百 $\mathrm{m}$ 程度) を念頭 に置いて計算領域を設定している．水平方向格子間隔 は, 投下点近傍から $0.5,2.5,10 \mathrm{~m}$ と段階的に変化させ ている．鉛直方向格子間隔は $1.0 \mathrm{~m}$ である.

\section{（2）計算条件}

土砂投下条件を表一 1 に示す.ここに, $Q\left(\mathrm{~m}^{3}\right):$ 土砂 投下総量, $q\left(\mathrm{~m}^{2}\right)$ : 単位長さ当たりの投下量, $\mathrm{t}_{\mathrm{D}}$ : 投下 時間, $\mathrm{U}_{\mathrm{D}}$ : 土砂流入速度である，底開バージの諸元は 様々であり，従って，その投下条件もまちまちである. 投下条件〜土砂堆積形状，投下条件〜濁りの拡散過程 等の関連といった課題についてはあまり検討されてお らず，検討結果をバージ諸元や投下方法にフィードバッ クするような状況にはない. 船長 $(L)$ は $50 \mathrm{~m}$, 底屝の開 口幅 $(W)$ は $4 \mathrm{~m}$, 土砂空隙率 $\left(\Phi_{D}\right)$ は 0.4 で一定とした. CASE1は，最も一般的と考えられる条件であり，積載 土砂量を空隙込みで $3,000 \mathrm{~m}^{3}$ とした。投下時間は底屝 の開口幅, 開口時間に依存するが, 既往の試験工事の例 を参照して，10s としている．但し，投下時間は砂質や 湿潤度で種々変化するようで, 湿潤な浚渫土やへドロ混 じりのものは投下時閒が長くなる. 表中の単位奥行き 当たり投下量は $q=Q / L$, 投下速度は, $U_{D}=q / W / t_{D}$ により計算される.

図ー 1に過去の試験工事において用いられた土砂の 粒度分布を示す, 図中の「ケース」は参考文献4)の試 験ケースをそのまま表示したものであり，本研究の計算 条件とは無関係である.このことは後述する表一 2 に ついても同様である. 現実の投下土砂は滑らかな粒度 分布を有するが, ここでは既述のとおり，本計算では堆 積土砂と濁りの成分の 2 粒径に代表させる. 土砂の平 均粒径は概ね $1 \mathrm{~mm}$ であり，粗な粖子の代表粓径として $d_{p}=1 \mathrm{~mm}$ を採用した. 土粒子密度は $\rho_{p}=2.65 \mathrm{~g} / \mathrm{cm}^{3}$, 最終沈降速度は $W_{p}=15.6 \mathrm{~cm} / \mathrm{s}$ である.

表ー2 2 は古土井》による試験工事において観測され た濁りの発生総量である。ここに, $m(\mathrm{~kg})$ : 濁質総発生 量, $Q\left(\mathrm{~m}^{3}\right)$ : 投下総量, $m / Q\left(\mathrm{~kg} / \mathrm{m}^{3}\right)$ : 濁りの発生原単 位, $r a$ : 濁質成分の体積率である. 但し, $r a=m / Q / \rho_{t}$, $\rho_{t}\left(\mathrm{~kg} / \mathrm{m}^{3}\right)$ : 濁りの密度である.この発生総量は投下点 から50 (上段) と $100 \mathrm{~m}$ (下段) 離れた地点で観測され た濃度フラックスを時間積分することにより求められ たものである. この值には，投下土砂に含まれる濁りと 誘起流動により海底から巻き上げられる濁りの両者が 含まれることになる.つまり，投下点から50あるいは $100 \mathrm{~m}$ の範囲内の海底面での濁りの収支を考慮したもの 

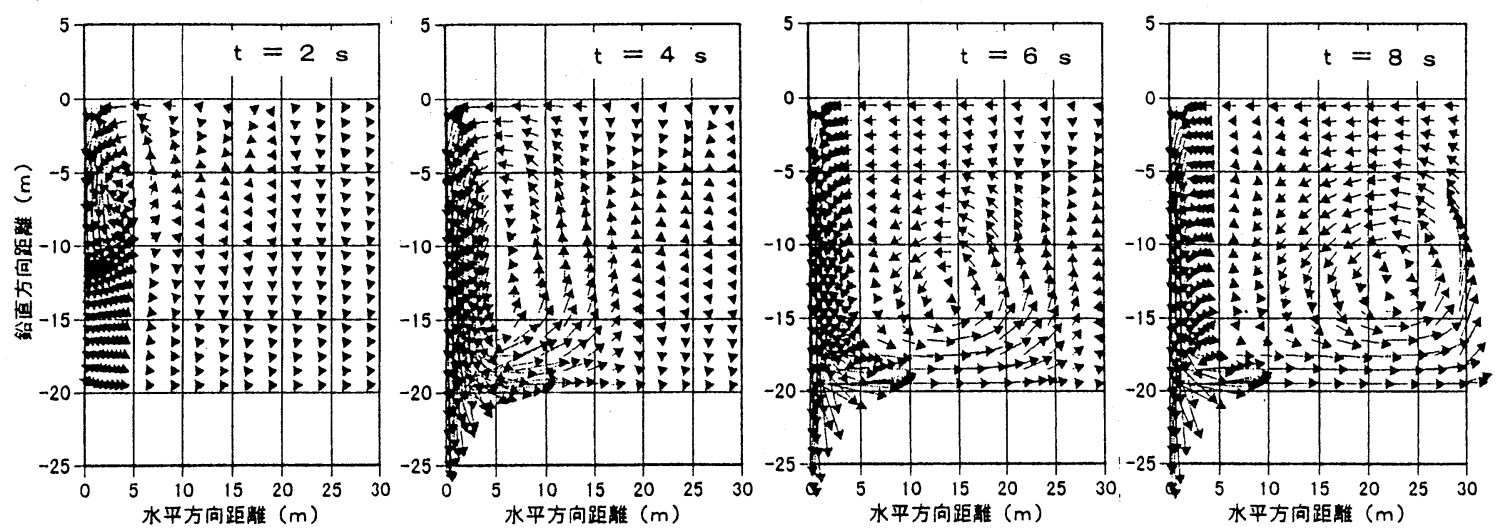

図-2 誘起流動場の形成過程
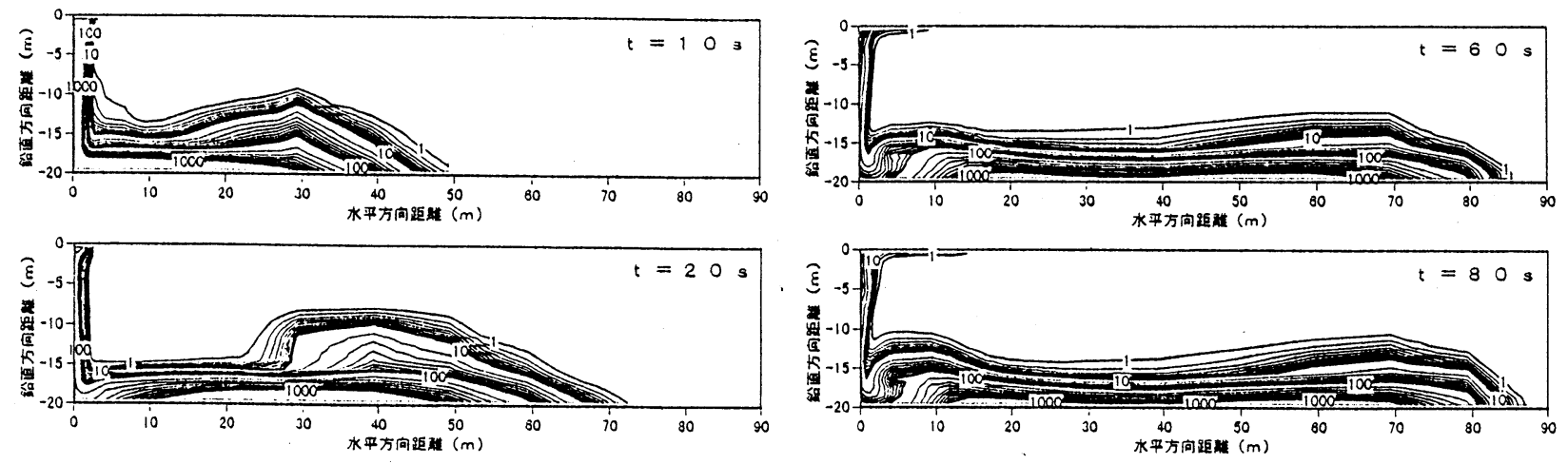

図-3 濁りの濃度分布の時間変化

になっている.この濁りの発生総量については 2 通り の利用方法が考えられよう.すなわち，まず第一は海底 面での濁りの収支をできる限り正確に計算して, 計算 結果の正当性を判断するのに利用することである．第 2 は海底面での濁りの収支を考慮せず，発生総量に等 しい濁りの挙動について計算することである．前者の 方法を選択することが望ましいことはいうまでもない， しかし, 既述のとおり高濃度混相流の乱流モデルの開 発状況等から判断して, 濁りの収支を精度高く計算で きるような状況にはない，そこで，ここでは後者の考 え方を選択した．表中に示したとおり，砂質により多 少異なるが，投下土砂量に対する濁りの体積率を計算 すると概ね $10^{-3}$ 程度である. 本計算では体積率を 0.001 で一定とした.

\section{（3）境界条件}

粒子と流体の境界条件については次のよう設定して いる.

a) 中心軸境界

$$
\Phi_{f, x}, \Phi_{p, x}, U_{f}, U_{p}, V_{f, x}, V_{p_{, x}}, k_{f, x}, \epsilon_{f, x}, C_{, x}=0.0
$$

b) 水面境界

$$
\Phi_{f, z}, \Phi_{p, z}, U_{f, z}, U_{p, z}, V_{f}, V_{p}, k_{f, z}, \epsilon_{f, z}, C_{, z}=0.0
$$

c) 水底境界

$\Phi_{f, z}, \Phi_{p, z}, U_{f}, U_{p}, V_{f}, V_{p_{, z}}, k_{f, z}, \epsilon_{f, z}, C_{, z}=0.0$

d) 遠方境界
$\Phi_{f, x}, \Phi_{p_{, x}}, U_{f, x}, U_{p, x}, V_{f, x}, V_{p_{, x}}, k_{f, x}, \epsilon_{f, x}, C_{, x}=0.0$ ここで, $U, V:$ それぞれ水平方向速度と鉛直方向速度, $x, z$ : 投下点を原点とした水平方向距離と鉛直方向距離 である.

\section{4. 計算結果}

\section{（1）誘起流動場の形成過程（ 10s）}

図一2に誘起流動場の形成過程（ 10s）の流体流動 場のベクトル図を示す，投下点下方において下向きの 流動が形成され，この流動が周囲流動を連行しながら 成長していることがわかる（t=2s）。強い誘起流動が 水底に到達すると, 投下点から水平方向に $15 \mathrm{~m}$, 水深 $13 \mathrm{~m}$ 付近に中心をもつ循環が形成される $(\mathrm{t}=6 \mathrm{~s})$. 循 環の中心は投下点から離れるように徐々に移動してい くことがわかる（t=8s）。この流動は投下が終了する と急速に減衰し, 投下終了後 $10 \mathrm{~s}$ 程度で明瞭な流動構 造は消失するようである. 鉛直方向のベクトルの大き さは, $6 \sim 7 \mathrm{~m}$ 程度である.

\section{（2）濁水塊の移動過程（10s～）}

図ー3にCASE1 の濁質濃度分布の時間変化を示す. 濃度はppm $(\mathrm{mg} / \mathrm{L})$ 表示となっている. $\mathrm{t}=10 \mathrm{~s}$ では循環 流九の影響により水平方向とともに鉛直方向にも濃度分 布が拡がっている. しかしながら，循環の影響が弱まっ 


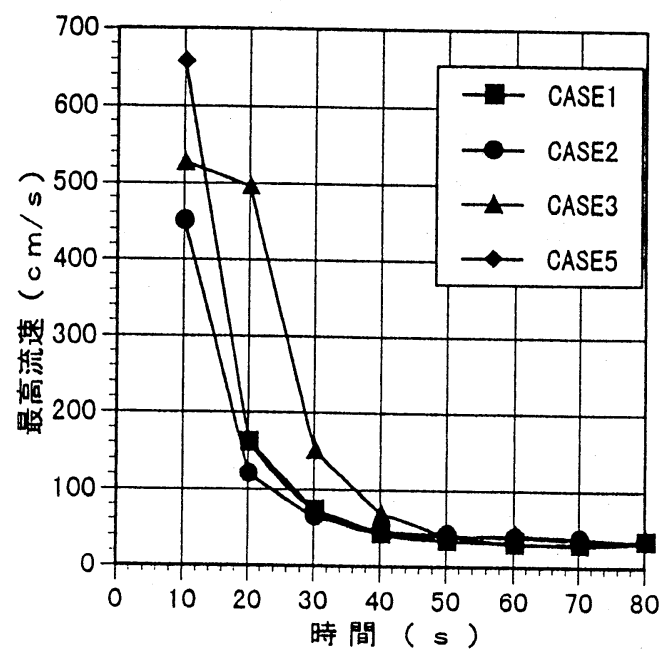

図-4 最大水平速度の减衰

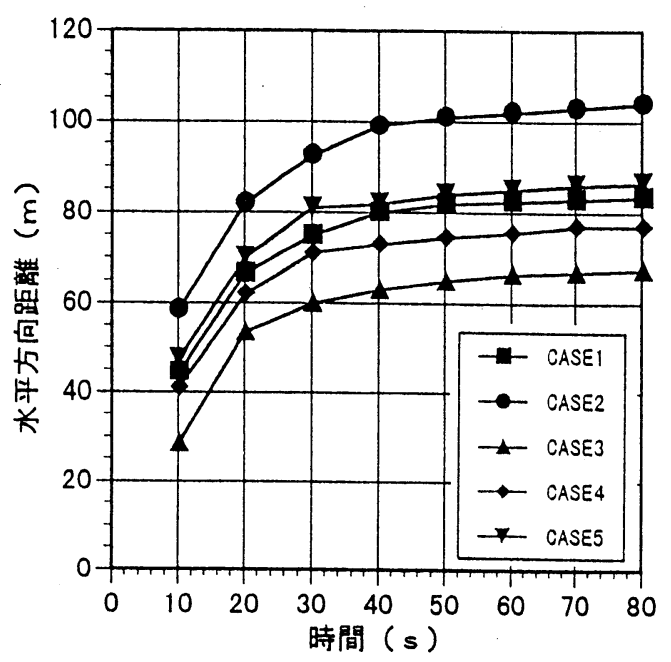

図-5 10ppm ラインの水平方向到達位置

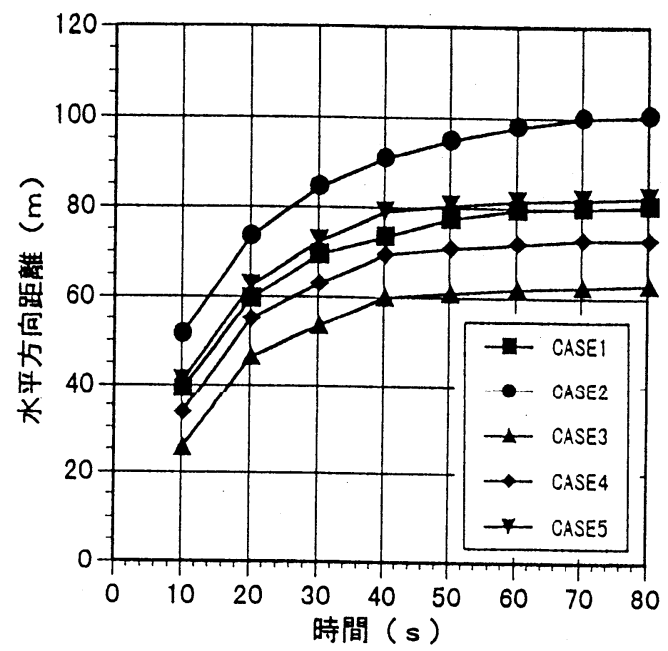

図-6 100ppm ラインの水平方向到達位置

ている $\mathrm{t}>20 \mathrm{~s}$ では，鉛直方向への成長は弱まり，もっ ぱら水平方向への拡がりが卓越している.こうした鉛 直方向への輸送は，投下時間の短いCASE2 において最 も顕著に現れた。いずれのケースについても，濁水塊 の最終的は形状（t=60〜80s）は中央部が若干薄い長細

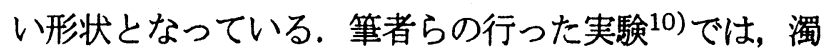

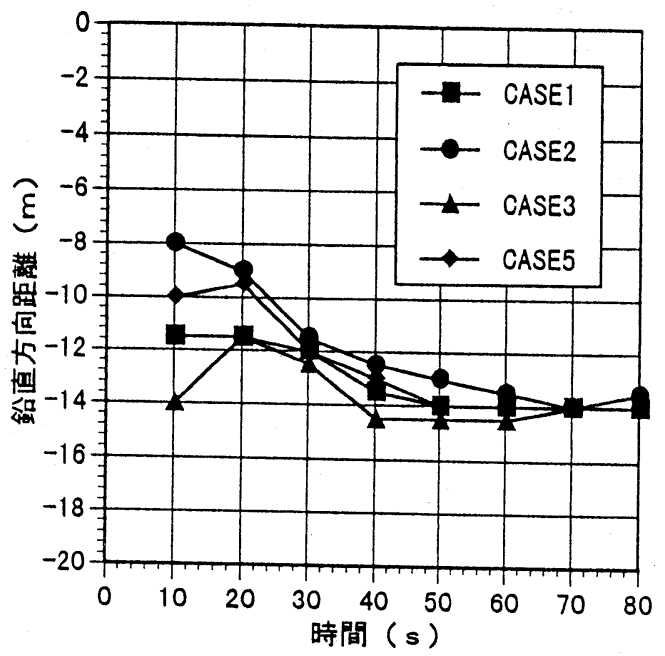

図-7 10ppm ラインの鉛直方向到達位置

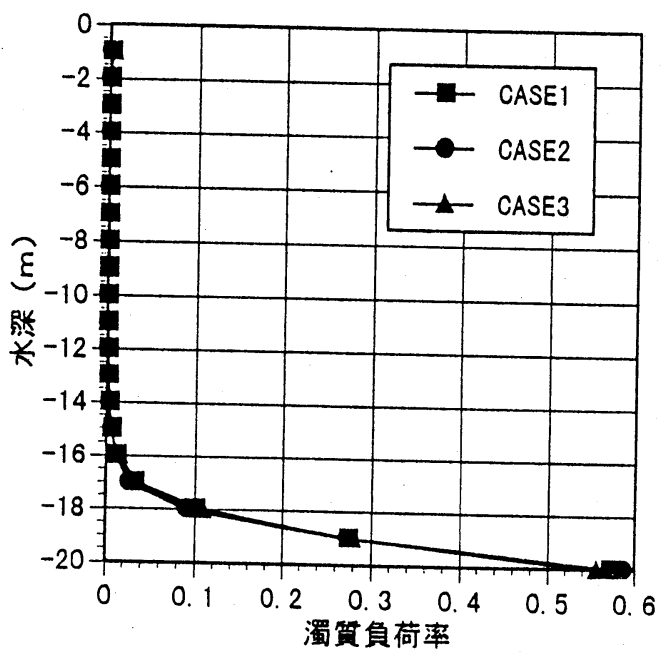

图-8 濁質量の鉛直分布

りによる密度効果が顕著でない場合には，循環により 水表面にまで濁りが桩がったのに対して，今回の数值 計算はそのような傾向は現れなかった。

図一 4 は計算領域内の最大水平流速の時間変化を示 している. CASE1, CASE5 ではt=10s, CASE2では

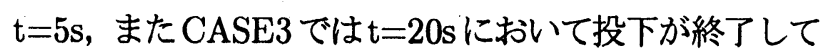
いる. $\mathrm{t}=10 \mathrm{~s}$ における最大流速の規模は 4 7m/sに達し ているが，その後急速に流速場は減衰する. 投下後 $50 \mathrm{~s}$ 程度になると $30 \mathrm{~cm} / \mathrm{s}$ 程度の流速になり，周囲環境流動 の規模との差異がなくなる.つまり, 投下後 1 分程度 経過すると, 周囲流動による移流や拡散が次第に顕著 になる，環境アセスメントにおいて，濁りの数値計算 は潮流場など周囲環境流動を対象に実施されるのが通 例となっているようであるが, 数 10 分や数時間以上の 現象をシミュレートするのであれば, 誘起流動場の影 響は考慮しなくて良いと言える．但し，その際には本 研究のような計算を別途実施して, 計算開始の初期濃 度を求める必要があると考えられる。

図ー5 と図ー6はそれぞれ10ppm と 100ppm の等濃 度線の水平方向到達位置の時間変化を, 計算した全ケー 
スについて併せて図示している. 図一5，図一6のグラ フの勾配から，いずれのケースについても， $\mathrm{t}=10 \sim 20 \mathrm{~s}$ にかけて等濃度線の移動速度は概ね $2 \mathrm{~m} / \mathrm{s}$ 程度である. その後, 減速して $t>50 \mathrm{~s}$ では澧度分布はほとんど延伸 していない. CASE1,CASE2,CASE3を比較すると, 同 一投下量の場合, 投下時間が短くなるほど水平方向の 到達距離が大きくなることがわかる。 つまり, 単位時 間当たりの投下量を小さくすることは濁りの水平方向 の拡がりを抑制する効果がある. 土砂投下点の近くに 污濁防止幕を設置しなければならない場合には, 誘起 流動場の拡がりを抑制するためには, 単位時間当たり の投下量を減少させることが有効である．また，現実 の土砂投下時間は $10 \mathrm{~s}$ 程度であることから, 誘起流動に よる濁りの水平方向拡散範囲は投下点から $100 \mathrm{~m}$ 以内で あると判断される．污濁防止幕が工事区域より $200 \mathrm{~m}$ 程 度外側に設置させることから，誘起流動の影響は污濁 防止幕までは及ばないと考えてよい，従って，現状の 使用方法では, 周囲環境流動による濁りの移流・拡散 との関連で濁りの流出抑制メカニズムは議論されるべ きである.

図ー7は 10ppm の等濃度線の鉛直方向の到達高さの 時間変化を示している. 但し, 底開バージ直下付近では 水表面まで高濃度領域が存在するが，この図では，この 付近の濃度分布を除外している. $t>20 \mathrm{~s}$ では時間とと もに等濃度線は下降している. 誘起流動場の影響が十 分弱まっていると考えられる $t>50 \mathrm{~s}$ では, $10 \mathrm{ppm}$ 以上 の濃度領域は水底から $6 \mathrm{~m}$ の範囲に限定される．また， ここでは図を掲載しなかったが，100ppmについても同 様の図を作成した結果, $100 \mathrm{ppm}$ 以上の濃度領域は水底 から高さ $4 \mathrm{~m}$ の範囲内であることがわかった。

図一8は濁質濃度の鉛直分布を示している．同図は

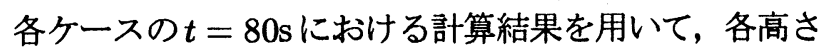
の濃度を水平方向に積分することによって求めた．投 下時間により若干の差異は認められるが，濃度分布は 概ね一様な形状となっている. 最下層 $1 \mathrm{~m}$ 内に濁りの発 生量の約 $55 \%$, 水底から $2 \mathrm{~m}$ までに $80 \%$ 以上が含まれ ることがわかる．濁りが垂下式と自立式の防止幕周辺 でどのような挙動特性を呈するのかは別途検討が必要 であるが，濁りの鉛直分布から自立式が存在しなけれ ば污濁流出抑制機構は期待できないと推察される.

\section{5. まとめ}

污濁拡散防止幕の濁りの流出抑制機構について，基 本的な現象理解が進んでいないことに鑑み，土砂直投 エにより生じる誘起流動場とそれによる濁りの移流拡 散過程を現地スケールの数値計算により検討した。但
し, 既述のとおり，本計算は種々の問題点を含んでいる と考えられる. 従って, 今回の計算結果は，一連の現 象に対する一つの粗い近似值であると考えている．主 要な計算結果を以下に要約する.

1) 土砂が鉛直落下寸る際に誘起される循環流れによっ て濁りの初期拡散過程は支配される. 但し, 土砂投下 終了後循環流れは急速に減衰する. 投下後 1 分程度経 過すると, 誘起流動場の流速の規模は高々 $30 \mathrm{~cm} / \mathrm{s}$ とな り，周囲流動の移流払散の影響を受けるようになる.

2)10ppm 以上の濃度分布の拡がりを基準にすれば, 濁りの水平方向拡散範囲は投下点から水平方向に高々 $100 \mathrm{~m}$, 水底から鉛直方向に約 $6 \mathrm{~m}$ 程度の範囲である. ま た, 濁りの発生総量のうち約 $80 \%$ は水底から高さ $2 \mathrm{~m}$ の範囲内に存在する.

3) 濁りの水平方向の搪がり範囲から判断して，投下 点から数百 $\mathrm{m}$ 以上離れて設置された污濁防止幕は, 周 囲環境流動により輸送される濁りの流出を抑制するこ とになる，一方，水底付近に污濁が集中することから， 自立式の防止幕が污濁流出抑制に有効に作用している と判断される.

4) 誘起流動場の拡がりを抑制するためには，単位時 間当たりの投下量を減少させることが有効であると考 えられる.

\section{参考文献}

1）小田一紀・重松孝昌・洮崎佳尚・山瀨晴義 : 污濁拡散防止膜 の効果に関する研究, 海岸工学論文集, 第 37 巻, pp.843$847,1990$.

2）小田一紀・重松孝昌・小林徹雄・岡本寛・山瀬晴義 : 垂 下膜・自立膜の近傍における沈降物質の拡散に関する鉛 直 2 次元実験, 海岸工学論文集, 第 40 巻, pp.976-980, 1993.

3）小田一紀・重松孝昌・野口達矢・武田将英: 污㺃防止膜 周辺の物質拡散の高精度予測手法に関する研究, 海岸工 学論文集, 第 43 巻, pp1151-1155, 1996.

4）古土井光昭 : 港湾工事における濁りの挙動に関する研究, 大阪大学学位詇文, 1989.

5）鶴谷広一・村上和男・中川康之・安井章雄：污濁防止膜 周辺の土砂拡散機構に関する現地観測, 海岸工学論文集, 第 43 巻, pp1146-1150, 1996.

6）鹳岡和夫・二瓶泰雄・八木宏 : 新しい固相モデルに基づ く固体一流体混相乱流ＬＥＳモデルの開発, 土木学会論 文集, No.533/II-34, pp.61-74, 1996.

7) S.E.Elghobashi and W.T.Abou-Arab : A twoequation turbulence model for two-phase Flow, Phys. Fluids, No.26(4), pp.931-938, 1983.

8）玉井昌宏・村岡浩爾・下屋陽八郎：2流体モデルを基礎と した $\mathrm{k}-\epsilon$ 乱流モデルによる粒子プルームの数值計算, 海 岸工学論文集, 第 40 巻, pp.1071-1075, 1993.

9) D.B.Spalding : Numerical computation of multiphase fluid flow and heat transfer, Recent Advance in Numerical Methods in Fluids edited by Talor and Morgan, Vol.1, Chap.5, 1978.

10）玉井昌宏・村岡浩爾・室田明・町田博紀 : 土砂直投工に おける濁りの初期拡散過程に関する研究, 土木学会論文 集, No.515/II-31, pp.77-86, 1995.

(1997.9.30受付) 